\title{
ECONOMY AND POLITICAL DISTRUST: EXPLAINING PUBLIC ANTI-PARTYISM IN THE CZECH REPUBLIC ${ }^{1}$
}

\author{
VLASTIMIL HAVLÍK
}

\begin{abstract}
There is little doubt in the current comparative politics literature about the importance of political parties in modern democracies, nor is there any doubt about the centrality of political parties in the democratic transitions in Central and Eastern Europe after the fall of communism. This holds true for the Czech Republic as well. However, the three most recent general elections in the Czech Republic have shaken the country. Electoral earthquakes are becoming common in the region, and it seems that the Czech Republic is being affected by what has been described in the literature as the decline of political parties. The main aim of the article is to explore sources of public anti-party sentiment in the Czech Republic. The analysis of data from a public opinion survey shows that public anti-partyism can be explained by a perceived lack of political representation that stems from both economic conditions and a feeling of low political efficacy.
\end{abstract}

Key words: political parties; anti-partyism; political representation; the Czech Republic

\section{Introduction}

There is little doubt in the current comparative politics literature about the importance of political parties in modern democracies. The vast majority of scholars argue that political parties are indispensable to the proper functioning of contemporary democracies (Sartori, 2005; Schattschneider, 2017; Dalton \& Weldon, 2005). Although the public initially viewed the position of political parties as relatively weak (Lijphart, 1992), they went on to become crucial actors in the democratic transitions in Central and Eastern Europe after the fall of communism. In the Czech Republic, the party system stabilized, coming to resemble its Western European counterparts (Bakke \& Sitter, 2005; Lewis, 2006; Tavits, 2008).

However, the three most recent general elections in the Czech Republic have shaken the once stable system (Haughton, Novotná, \& Deegan-Krause, 2011; Havlík, 2015). Even more importantly, most of the electoral changes could account for the unprecedented rise of political actors who have been questioning the role of political parties in the political

1 This article was written as part of the Radicalization of Politics in Central Europe in Times of Crises (GA17-09296S) sponsored by the Czech Science Foundation. 
process. All the same, according to the most recent wave of European social surveys conducted in 2016, almost $78 \%$ of Czechs do not trust political parties.

Given the crucial role of political parties in democratic representation, the main aim of the present article is to explore sources of public resentment towards party democracy in the Czech Republic; in other words, to explore who is more likely to be critical of the role of political parties in the political system.

The paper is structured as follows. First, I introduce the concept of anti-partyism and explain how I will approach it in the article. I also place anti-partyism within the current context of party politics in the Czech Republic and develop my hypotheses. In the next part, I describe the data and the method of analysis. A discussion of the results follows and the article ends with concluding remarks.

\section{The concept of anti-partyism}

As Dalton and Weldon argued, "perhaps no institution is so closely identified with the process of representative politics as are political parties" (Dalton \& Weldon, 2005). Despite the long history of suspicion towards political parties among politic al thinkers (Poguntke, 1996), the majority of scholars agree that political parties are an essential component of contemporary liberal democracies, that they are at the centre of political processes and represent one of the crucial elements in the chain of democratic political representation. Some scholars even contend that political parties are indispensable to modern democracy. In his classic study of political parties and party systems, Sartori described representation of citizens in Western democracies through and by political parties as "inevitable" (Sartori, 1968) and some scholars even argue that strongly institutionalized political parties play a critical role in fostering economic development (Bizzarro et al., 2018; Rasmussen \& Knutsen, 2017).

In spite of the proclaimed inevitability of political parties, in the last few decades we have seen what has been described as the "decline of political parties" (Clarke \& Stewart, 1998) or "a crisis of party" (Daalder, 1992). Scholars have pointed to a number of different indicators of the decreasing importance of political parties, including an unprecedented drop in party membership (van Biezen et al., 2012), increasing levels of electoral volatility (Pedersen, 1979; Mainwaring et al., 2017) and a decline in party identification (Schmitt, 1989; Dalton, 2002). There is also a large body of literature about the "cartelization" of political parties (Katz \& Mair, 1995) that describes the detachment of political parties from society and their fusion with the state, and many countries have experienced the rise of "anti-party parties" (Mudde, 1996). The weakened position of political parties has been accompanied by the phenomenon of anti-partyism or, to put it more precisely, by anti-party sentiment among both the public and political actors.

As Daalder put it, 'the assumed 'crisis of parties' is mainly a euphemism for a dislike of parties" (Daalder, 1992, p. 285). Today, cynicism about political parties seems to be a common element of the discourse among political elites and the public at large (Mair, 2002). Indeed, while in the past political parties were viewed as pillars of democracy, they are now commonly viewed as an impediment to the democratic process. It is "chic to be anti-partisan today" (Dalton \& Weldon, 2005). But what is anti-partyism? 
Generally speaking, anti-partyism refers to an attitude critical of political parties or even one that rejects political parties and their proclaimed importance in the political system. It is a "disaffection from parties or even their rejection" (Poguntke \& Scarrow, 1996) that is part of a more general "political malaise" (Bélanger, 2004). Nevertheless, depending on the object and intensity of this critical assessment, anti-partyism can take several different forms. In his seminal article titled "The Crisis of a Party", Hans Daalder distinguished between two types of anti-party sentiment: the selective rejection of the party and the denial of a party (Daalder, 1992, see also Poguntke \& Scarrow, 1996; see also Linek, 2003; Schedler, 1996; Torcal, Gunther, \& Montero, 2002).

Although potentially stemming from specific anti-party positions (a negative attitude towards particular political parties), the core idea of the denial of a party or so-called general anti-partyism and its consequences are more radical, in that the common solution-voting for another political party that represents "politics as usual"-is not enough. One solution may be to vote for a political party that has anti-party attitudes, but electing such a party means taking a more or less explicit step towards a deeper change aimed at weakening or even eliminating political parties from the political system. This form of opposition goes beyond the norm of competitive party politics. It undermines the legitimacy of a political system based on political pluralism and stemming from the contestation of political parties (i.e. from party democracy) and calls for change.

This not to say that it is always easy to empirically distinguish the two types of antipartyism (general and specific) (but see Linek, 2003; Torcal et al., 2002). But if we are concerned with the quality of democracy (and many studies point to the recent decline of democracy in the world, so we should be), generalized anti-partyism is the type of antiparty sentiment we should concentrate on first. Therefore, in the rest of the article, the term anti-partyism will be understood as general criticism or even the rejection of the idea that political parties are an important institution in a political system, that is, the rejection of party democracy.

\section{Anti-partyism in the Czech context}

The Czech Republic was considered an example of a successful transition from communism to democracy. The (re-)building of a competitive and usually stable party system was an important part of the story of post-1989 Czech exceptionalism (Balík et al., 2017; Klíma, 1998). Indeed, rather than fitting into the picture of constant changes in party politics in other post-communist countries, Czech political parties and the system were reminiscent of their West European counterparts. The ideological underpinnings of the electorally successful political parties were similar to those in Western Europe. The effective number of political parties remained low and electoral volatility was the lowest of all the Central and Eastern European countries (Havlík, 2015; Powell \& Tucker, 2014).

Nevertheless, recent political developments in the Czech Republic indicate that the premise that political parties are an essential part of the restored political pluralism is no longer uncontested. Electoral volatility has risen significantly and the last three general elections have not only shaken the position of the established political parties but also challenged the idea of party democracy. The unprecedented increase in volatility is 
primarily due to the emergence of political actors who not only criticize the established political parties but also question the role of political parties and party competition in general. So it is hardly surprising the latest wave of European social surveys conducted in 2016 found that almost $78 \%$ of Czechs did not trust political parties (only people in Portugal, severely hit by the Great Recession, and in Poland have less trust in political parties).

Three new challenger parties (VV, ANO, and Dawn/SPD) entered parliament, together gaining $11 \%$ of the vote in $2010,25 \%$ in 2013 and $43 \%$ in 2017. Despite the differences in discourse, the three new political parties were all fiercely critical of the establishment, accusing the existing political parties of corrupt behaviour and incompetence. What is important, though, is that the appeals of these political parties have gone beyond mere antiestablishment rhetoric or specific anti-party sentiment.

Their visions of a new system of governance were based either on introducing elements of direct democracy (VV, Dawn/SPD) or on turning the state into a highly centralized business-model run by managers (ANO) (see e.g. Havlík, 2015). The three new parties have also implemented specific features of party organization that challenge the way established political parties work. They more or less explicitly refused to build a broad membership base and instead run their political parties like highly centralized private companies (Kopeček, 2016; Kopeček \& Svačinová, 2017). On top of that, none of the three parties use the term "party" in their name and ANO and Dawn/SPD were registered as political movements, symbolically rejecting partyism as their organizational form.

Although the Law on Political Parties does not distinguish between the the two organizational forms (political parties and political movements), the symbolism is important for several reasons. The term movement is used to describe organizations that emerge from below and may create the impression that they are a more direct representation of the people. Therefore, statements emphasizing that ANO is not a political party have become a recurrent theme in the party's narrative. Babiš claimed that he founded ANO 2011 as a "Civic Forum for the future" (Česká televize, 2013), a reference to the broad movement that emerged during the fall of communism and famous for, among other things, its slogan "political parties are for partisans, the Civic Forum is for everyone". Similarly, Okamura's (SPD) emphasis on direct democracy can be seen as a means of bypassing the world of political parties. The decision to establish formal political movements (instead of parties) was also a pragmatic move that reflects the public's suspicious attitude towards political parties and partisan politics (as Babiš's key advisor stated: "people hate new political parties"Jankajová, 2013) that dates back to the era of communism, to presidents Beneš and Masaryk and even to the $19^{\text {th }}$ century (Havelka, 1998).

The rise in discursive anti-partyism in the party system was coupled with the public's negative views of political parties. Moreover, an examination of the long-term trend clearly shows that there was much less public anti-partyism in the past. In the 1996 post-election study carried out by the Czech Academy of Sciences, almost $74 \%$ of respondents agreed that political parties were necessary for democracy and only $6 \%$ did not, but when the survey was repeated in the mid-2000s, barely half $(51 \%)$ agreed political parties were indispensable in a democracy and 33\% disagreed (Čadová, 2017). So what is driving the high level of public anti-partyism in the Czech Republic? 


\section{Causes of anti-partyism: Theoretical expectations}

Why are people critical of the role political parties play in a democracy? The main argument tested in this article is quite simple, and it follows the long tradition of research on political trust in democratic political systems. I argue that the main reason behind public antipartyism in the Czech Republic is dissatisfaction with the political system.

The economy is generally considered one of the strongest predictors of support for a political system and its institutions. As noted by van der Meer, "The economy is an important driver of political trust" (van der Meer, 2017). The rich literature on economic voting shows that governments are punished for a country's poor economic performance (sociotropic economic voting) or the individual's bad economic situation (pocketbook economic voting) (see e.g. Harper, 2000; Lewis-Beck \& Paldam, 2000; G. B. Powell \& Whitten, 1993). There is no reason to expect that the relationship between the e conomy and the assessments of politics should work differently for political parties.

The existing literature on public anti-partyism confirms the relationship between the economy and critical attitudes towards political parties. In terms of the level of anti-partyism, Webb found being unemployed correlated positively with negative perceptions of the economy in Great Britain (Webb, 1996). Similarly, Gigendil et al. confirmed the effect of negative views of the macroeconomic situation on anti-partyism in Canada (although they found no effect for unemployment) (Gidengil, Blais, Nevitte, \& Nadeau, 2001). Torcal et al. also found a relationship between anti-partyism and negative views of both the individual's economic situation and that of the country (Torcal et al., 2002). Therefore, I formulated the following hypotheses:

H1: People who think their economic situation is bad are more likely to hold anti-party attitudes.

H2: People who think the country's economy is performing badly are more likely to hold anti-party attitudes.

In addition to the link with the economy and living standards, there is good reason to expect that negative attitudes towards the need for political parties stem from general dissatisfaction with how they function. As stated above, the key function of political parties is to represent the interests of the people. In a parliamentary democracy such as that in the Czech Republic, political parties are the most important institution linking society and government. The current model of democracy is based on political parties, on their capacity to form governments and pass legislation that is supposed to reflect the interests of the people. It is no coincidence that Article 5 of the Constitution of the Czech Republic states that " $[t]$ he political system is founded on the free and voluntary formation of and free competition among those political parties" and that Czech cabinets are based on cooperation among political parties and that the state provides political parties with relatively generous levels of funding (Haughton \& Havlík, 2017). Put simply, the democracy in the Czech Republic is a party democracy and the political parties and their leaders and MPs are largely responsible for its proper functioning and are among the first to be blamed if it malfunctions. 
Following the early theoretical argument formulated in Easton's systemic theory (Easton 1965, 1975), the survival of a political system depends on support from its environment, especially diffused support. In other words, a lower level of specific support, primarily based on system performance, reduces the level of diffuse support. In our case the diffuse support is the indispensable role the political parties play in the political system. Gigendil et al. found that lack of external political efficacy, distrust of politicians and negative views of political parties correlated positively with anti-partyism in Canada (Gidengil et al., 2001). Similar findings were reported by Torcal, Gunther, and Montero (2002) in their research on anti-partyism in Southern Europe, by Tan in his study of antipartyism in Indonesia (Tan, 2012) and by Sing in his study of attitudes towards political parties in Hong Kong (Sing, 2004). Some studies have predicted anti-partyism level by examining identification with political parties (Gidengil et al., 2001). However, this indicator is really a measure (albeit an indirect one) of a critical stance towards political parties (see e.g. Klar \& Krupnikov, 2016) rather than of anti-partyism as such. This is tautological and so party identification will not be included in the analysis. Instead I have formulated the following hypotheses:

H3: People who think that their interests are not represented are more likely to hold antiparty attitudes.

H4: People who think that politicians do not care what people think are more likely to hold anti-party attitudes.

The established research on public anti-partyism emphasizes that there are other drivers of public anti-partyism, and these are included in the analysis. Following previous research on political trust among the public, Torcal et al. (2002) highlight the fact that political socialization and the political context in which political socialization takes place drive attitudes towards political parties. The argument is a simple one and combines two presumptions: first, people born in the same era share similar values, because they grew up in a similar political, social and economic environment. Political socialization studies show that late pubescence and early adolescence seem to be most important in the formulation and internalization of political attitudes (Alwin, 1993; Sears, 1975). An analysis conducted by Torcal, et al. (2002) in Spain confirmed that the oldest generations socialized during the nondemocratic periods of regime development were more critical of political parties (but this was also true of the youngest generation, who had grown up in the era of dealignment). In addition to age, I will also control for gender and religion.

Views of political parties may also be related to political interest. Contemporary political systems in multilevel settings include both subnational levels of governance and limits imposed by membership of supranational organizations, most notably in the European Union. The space within which independent economic policies can be pursued has been diminishing over time due to the process of globalization. The role of political parties has weakened despite their formal (legal) position remaining the same. They form electoral platforms, recruit political personnel and eventually form governments. But their real impact on policies is smaller than ever and it is reasonable to expect less from political parties in terms of real impact on policy-making (Mair, 2013). Moreover, democracy is necessarily 
messy, requires compromise and sometimes less than transparent backdoor bargaining. Logically then, the more people care about politics, the greater their capacity to understand the negative side of democracy and party politics. Consequently, they are less critical of or at least have greater patience with political parties. Gigendil et al. (2001) showed that people with greater interest in politics had less negative opinions of Canadian political parties. Therefore, I will also control for level of political interest.

\section{Data and method}

The data for this investigation into the sources and electoral consequences of anti-partyism in the Czech Republic comes from a regular public opinion survey conducted in February 2018 by the Centre of Public Opinion Research at the Czech Academy of Sciences (CVVM 2018). The survey is based on a representative sample of 1,119 citizens and covers a variety of questions including standard socio-demographics and selected political attitudes. The survey also enquired about the presidential election and included a question on attitudes to party democracy and views of alternative political regimes.

The drivers of public anti-partyism will be examined using binary logistic regression. The dependent variable is "anti-partyism" and is constructed as a dummy variable based on the following question:

Some people say that political parties are essential to the proper functioning of the political system in the Czech Republic. Other people think that political parties are unnecessary. On the card there is a scale where 1 means that political parties are essential to the proper functioning of the political system and 5 means that they are unnecessary. Please indicate which number best reflects your opinion.

The list of the independent variables can be found in Appendix 1.

Odds ratios and level of significance were used to interpret the effects of the independent variable on the dependent variable.

\section{Results}

One-fifth $(20.4 \%)$ of the respondents thought that political parties were not essential to a well-functioning political system, which is quite a high proportion. What are the predictors of anti-party attitudes in the Czech Republic? The model of binary logistics shows that there are several indicators predicting anti-party attitudes in the Czech Republic. The results of the model regression are presented in Table 1.

First of all, the hypotheses relating to the state of the economy were confirmed to some extent. While having a negative view of one's household economic situation was not a significant predictor of anti-party attitudes, people who thought the Czech economy was in a very bad way were three times more likely to be anti-party. These mixed results show that people do not necessarily blame political parties for their personal economic situation but it is clear that the role of political parties is strongly related to views of the Czech economy and a poorly performing economy undermines public perceptions that party democracy is essential to the political system. 
Table 1. Results of the model explaining anti-partyism

\begin{tabular}{|c|c|c|c|c|}
\hline \multicolumn{2}{|l|}{ Variable } & \multirow{2}{*}{$\begin{array}{c}\mathbf{B} \\
-.717 \\
\end{array}$} & \multirow{2}{*}{$\begin{array}{l}\text { S.E. } \\
.188 \\
\end{array}$} & \multirow{2}{*}{$\begin{array}{c}\text { Odds ratio } \\
.488^{* * * *} \\
\end{array}$} \\
\hline Gender & (ref. man) & & & \\
\hline \multirow[t]{5}{*}{ Generation } & War (ref.) & & & \\
\hline & Prague Spring & .262 & .419 & 1.300 \\
\hline & Normalization & .461 & .304 & 1.585 \\
\hline & Velvet & .143 & .237 & 1.154 \\
\hline & Dealignment & .434 & .265 & 1.544 \\
\hline Catholic & (ref. other) & -.143 & .214 & .867 \\
\hline \multirow[t]{4}{*}{ Education } & University (ref.) & & & \\
\hline & Elementary & .510 & .329 & 1.665 \\
\hline & Vocational & .018 & .273 & 1.018 \\
\hline & High school & -.079 & .278 & .924 \\
\hline \multirow[t]{3}{*}{ Interest in politics (media) } & (ref. often) & & & \\
\hline & Sometimes & .322 & .245 & 1.380 \\
\hline & Rarely & .931 & .287 & $2.537 * * *$ \\
\hline Interest in politics (subjective) & (ref. low) & .372 & .230 & 1.451 \\
\hline Economy (pocketbook) & (ref. good) & -.196 & .283 & .822 \\
\hline Economy (sociotropic) & (ref. good) & 1.102 & .542 & $3.009 * *$ \\
\hline Political efficacy (internal) & (ref. high) & .441 & .254 & $1.554 *$ \\
\hline Political efficacy (external) & (ref. high) & .898 & .190 & $2.454 * * *$ \\
\hline Constant & & -2.173 & .434 & .114 \\
\hline Nagelkerke R2 & & & & 0.14 \\
\hline
\end{tabular}

$* \mathrm{p}<.05, * * \mathrm{p}<.01, * * * \mathrm{p}<.001$.

Similarly, feelings of low political efficacy increase the odds of having an anti-party attitude. What is important is that this effect was valid for both the internal and external efficacy measures. Strong disagreement with the statement that a person's legitimate interests can be articulated increased the odds of having anti-party attitudes by more than one and a half times.

Similarly, strong disagreement with the statement that politicians are interested in what people think increased the odds of having anti-party attitudes by almost two and a half times. Put simply, if people think they are not represented properly by their elected representatives and that their interests are not taken into account during decision making, they tend to have doubts about the system of party democracy. This is not a surprising finding and is in line with both the theory of political systems and empirical studies of political trust. Also, the literature on both descriptive representation (e.g. Poláková \& Kostelecký, 2016) and fulfilment of government promises (Gregor, 2018; Svačinová, 2016; Škvrňák, 2015) shows that the real state of political representation in the Czech Republic is far from perfect. For instance, the governing parties were able to fulfil only one quarter of their pledges in 2007- 
2010, and less than $40 \%$ in 2010-2013. As stated by Roberts (2016, p. 45), "throughout the transition, the connection between government promises or ideologies and policy choices has been less than adequate".

The model also shows that political interest (measured by extent to which politics is followed in the media) matters: the odds of having anti-party attitudes is two and a half times higher among people who never or rarely follow politics than among those who often follow politics in the media. This is a very important finding. It seems that anti-partyism in the Czech Republic is not related merely to low political efficacy but also to indifference and to lack of effort to seek out information about politics, particularly in the media (the subjective lack of interest in politics in the Czech Republic per se also correlated positively with antiparty attitudes but the effect disappeared in the regression model).

Level of education had no significant effect on holding anti-party attitudes which means that formal education does not automatically lead to more critical attitudes towards partisanship. Last but not least, the odds of men having anti-party attitudes were twice that of women, which is a bit surprising since the literature studying the effects of gender on political attitudes has tended to find the opposite. Lower levels of political interest and political efficacy among women are usually explained in terms of the dominant role of men in politics. One possible explanation may lie in the literature describing a gender gap in votes for radical right parties, with most of the support tending to come from men, and in the explanation that populist attitudes are more often held by men (Spierings \& Zaslove, 2017; Harteveld, van der Brug, Dahlberg, \& Kokkonen, 2015).

\section{Conclusion}

Recent developments in party politics in the Czech Republic have led to both one of the highest levels of public anti-party attitudes in Europe and the unprecedented electoral success of political parties with elements of anti-partyism in their political discourse. The present article aimed to explain why people hold anti-party attitudes, defined here as the rejection of the role of political parties in the Czech political system, and to examine their preferred alternatives to party democracy.

As for the predictors of anti-party attitudes, the main message of the analysis is twofold. First, political parties are criticized for not listening to the people, for the country's poor economic performance and for not fulfilling their representative functions. In other words, people who have anti-party attitudes tend not to believe political parties are competent. Looking at the literature on the decline of political parties in general and in the Czech Republic in particular, the distance between political parties and society has increased in recent decades. Also, the literature dealing with how political parties perform indicates that political representation is far from perfect.

Fixing the situation is no easy task but what is clear is that political parties-if they stick to the idea of party democrac — should invest their resources into reducing this gap and acting responsibly towards voters, not make foolish promises and listen more carefully to the people. Nevertheless, Mair's "ruling the void" argument leaves us feeling slightly sceptical as the objective capacity of political parties to govern has decreased over time. Second, the data show that there may be another way —albeit closely related to the previous one—of 
boosting support for party democracy. People who are not interested in politics tend to have anti-party attitudes. While raising interest in politics is no easy task and, although the decline in electoral turnout and party membership are a widespread pan-European phenomenon, the data clearly show that low political interest is also related to lower levels of support for party democracy. A possible direction for future research is to investigate the alternatives for those who are critical of party democracy. Populism and technocracy seem to be likely substitutes (Caramani, 2017; Mair, 2002; Bickerton \& Accetti, 2017) and there are more extreme alternatives (Mudde 1996). None seem to be good news for the prospects of liberal democracy.

Acknowledgment: I wish to thank Andrew Roberts, and the anonymous reviewers for their helpful comments.

\section{Appendix 1: Overview of the variables}

\begin{tabular}{|c|c|c|c|}
\hline Variable & Values & Old variable & Old values \\
\hline \multirow{2}{*}{ Gender } & $1=$ male & IDE.8 Gender & $1=$ male \\
\hline & $0=$ female & $0=$ female & $0=$ female \\
\hline \multirow{5}{*}{ Generation } & $\begin{array}{l}1=\text { War and building } \\
\text { communism } \\
\text { generation }\end{array}$ & IDE.2 Age & 74 and older \\
\hline & $\begin{array}{l}2=\text { Prague Spring } \\
\text { generation }\end{array}$ & & $65-74$ \\
\hline & $\begin{array}{l}3=\text { Normalization } \\
\text { generation }\end{array}$ & & $64-45$ \\
\hline & $4=$ Velvet generation & & $44-35$ \\
\hline & $\begin{array}{l}5=\text { New democracy } \\
\text { generation }\end{array}$ & & 34 and younger \\
\hline \multirow[b]{2}{*}{ Religion } & $1=$ Catholic & $\begin{array}{l}\text { IDE.7 Church, } \\
\text { religious community }\end{array}$ & $1=$ Roman Catholic \\
\hline & $0=$ other & & $\begin{array}{l}2=\text { Protestant } 3=\text { Jew; } \\
4=\text { Muslim; } 5=\text { other church; } \\
6=\text { atheist }\end{array}$ \\
\hline \multirow{4}{*}{ Education } & $1=$ up to elementary & IDE.6b Education & $\begin{array}{l}1=\text { unfinished junior high school; } \\
2=\text { junior high school }\end{array}$ \\
\hline & $2=$ vocational & & $\begin{array}{l}3=\text { vocational; } 4=\text { high school } \\
\text { without leaving certificate }\end{array}$ \\
\hline & $3=$ high school & & $\begin{array}{l}5=\text { specialized high school with } \\
\text { leaving certificate; } 6=\text { general high } \\
\text { school without leaving certificate }\end{array}$ \\
\hline & $4=$ higher education & & $\begin{array}{l}6=\text { higher specialized schools; } \\
7=\text { bachelor's degree; } 8=\text { master's } \\
\text { degree; } 9=\text { doctoral degree and } \\
\text { higher }\end{array}$ \\
\hline
\end{tabular}




\begin{tabular}{|c|c|c|c|}
\hline Variable & Values & Old variable & Old values \\
\hline \multirow{3}{*}{$\begin{array}{l}\text { Interest } \\
\text { in politics } \\
\text { (media) }\end{array}$} & $1=$ often & $\begin{array}{l}\text { PV.23a How often - } \\
\text { follow politics in the } \\
\text { media }\end{array}$ & $1=$ often \\
\hline & $2=$ sometimes & & $2=$ sometimes \\
\hline & $3=$ rarely/never & & $3=$ rarely $; 4=$ never \\
\hline \multirow{2}{*}{$\begin{array}{l}\text { Interest } \\
\text { in politics } \\
\text { (subjective) }\end{array}$} & $1=$ not interested & $\begin{array}{l}\text { PO.45b Interest in } \\
\text { politics - developments } \\
\text { in the Czech Republic } \\
\end{array}$ & $\begin{array}{l}3=\text { not really interested; } \\
4=\text { not interested at all }\end{array}$ \\
\hline & $0=$ interested & & $\begin{array}{l}1=\text { very interested; } 2=\text { fairly } \\
\text { interested }\end{array}$ \\
\hline \multirow{2}{*}{$\begin{array}{l}\text { Economy } \\
\text { (pocketbook) }\end{array}$} & $1=$ bad & $\begin{array}{l}\text { EV.10 View of the } \\
\text { Czech economy }\end{array}$ & $4=$ fairly bad; $5=$ very bad \\
\hline & $0=$ other & & $\begin{array}{l}1=\text { very good } ; 2 \text { = fairly good } \\
3=\text { neither good, nor bad }\end{array}$ \\
\hline \multirow{2}{*}{$\begin{array}{l}\text { Economy } \\
\text { (sociotropic) }\end{array}$} & $1=\mathrm{bad}$ & $\begin{array}{l}\text { IDE.1 Household } \\
\text { finances }\end{array}$ & $4=$ fairly bad; 5 = very bad \\
\hline & $0=$ other & & $\begin{array}{l}1=\text { very good } 2=\text { rather good } \\
3=\text { neither good }, \text { nor bad }\end{array}$ \\
\hline \multirow[t]{2}{*}{$\begin{array}{l}\text { Political } \\
\text { efficacy } \\
\text { (internal) }\end{array}$} & $1=$ low & $\begin{array}{l}\text { PS.16e Statements } \\
\text { - people are able to } \\
\text { influence what elected } \\
\text { politicians do }\end{array}$ & $4=$ strongly disagree \\
\hline & $0=$ other & & $\begin{array}{l}1=\text { strongly agree } ; 2=\text { agree } \\
\text { somewhat } 3=\text { disagree somewhat }\end{array}$ \\
\hline \multirow{2}{*}{$\begin{array}{l}\text { Political } \\
\text { efficacy } \\
\text { (external) }\end{array}$} & $1=$ low & $\begin{array}{l}\text { PS.16g Statements - } \\
\text { elected politicians care } \\
\text { what people think } \\
\end{array}$ & $4=$ strongly disagree \\
\hline & $0=$ other & & $\begin{array}{l}1=\text { strongly agree; } 2=\text { agree } \\
\text { somewhat; } 3=\text { disagree somewhat }\end{array}$ \\
\hline \multirow{2}{*}{$\begin{array}{l}\text { Anti- } \\
\text { partyism }\end{array}$} & $1=$ anti-party & $\begin{array}{l}\text { EVS1 Political parties } \\
\text { are essential, needed }\end{array}$ & $4 ; 5$ \\
\hline & $0=$ others & & $1-3$ \\
\hline
\end{tabular}

\section{References}

Alwin, D. (1993). Attitude development in adulthood: The role of generational and life-cycle factors. In D. Krebs \& P. Schmidt (Eds.), New directions in attitude measurement (pp. 59-91). New York: De Gruyter.

Bakke, E., \& Sitter, N. (2005). Patterns of stability: Party competition and strategy in Central Europe since 1989. Party Politics, 11, 243-263.

Balík, S., Hloušek, V., Kopeček, L., Holzer, J., Pšeja, P., \& Roberts, A.L. (2017). Czech politics: From west to east and back again. Leverkusen: Barbara Budrich Publishers.

Bélanger, É. (2004). Antipartyism and third-party vote choice: A comparison of Canada, Britain, and Australia. Comparative Political Studies, 37(9), 1054-1078. 
Bickerton, C., \& Accetti, C.I. (2017). Populism and technocracy: Opposites or complements? Critical Review of International Social and Political Philosophy, 20, 186-206.

Biezen, I. van, Mair, P., \& Poguntke, T. (2012). Going, Going,... Gone? The decline of party membership in contemporary Europe. European Journal of Political Research, 51(1), 24-56.

Bizzarro, F., Gerring, J., Knutsen, C.H., Hicken, A., Bernhard, M., Skaaning, S.E., Michael Coppedge, M., \& Lindberg, S. I. (2018). Party strength and economic growth. World Politics, 70(2), 275-320.

Caramani, D. (2017). Will vs. reason: The populist and technocratic forms of political representation and their critique to party government. American Political Science Review, 111(1), 54-67.

Clarke, H. D., \& Stewart, M.C. (1998). The decline of parties in the minds of citizens. Annual Review of Political Science, 1, 357-378.

Čadová, N. (2017). Postoje obyvatel České republiky k politickým stranám - záŕí 2017. Available at: https://cvvm.soc.cas.cz/media/com_form2content/documents/c2/a4441/f9/pv171030.pdf)

Česká televize (2013). 'Babiš chystá Občanské fórum proti korupci a hledá lídra.' Available at: http:// www.ceskatelevize.cz/ct24/domaci/136958-babis-chysta-obcanske-forum-proti-korupci-a-hledalidra/.

Daalder, H. (1992). A crisis of party? Scandinavian Political Studies, 15(4), 269-88. https://doi. org/10.1111/j.1467-9477.1992.tb00022.x

Dalton, R. J. (2002). The decline of party identifications. In R. J. Dalton \& M. Wattenberg (Eds.), Parties without partisans: Political change in advanced industrial democracies (pp. 19-36). Oxford: Oxford University Press.

Dalton, R. J., \& Weldon, S.A. (2005). Public images of political parties: A necessary evil? West European Politics, 28(5), 931-951.

Easton, D. (1965). A systems analysis of political life. New York: John Wiley.

Easton, D. (1975). A re-assessment of the concept of political support. British Journal of Political Science, 5(4), 435-457.

Gidengil, E., Blais, A., Nevitte, N., \& Nadeau, R. (2001). The correlates and consequences of antipartyism in the 1997 Canadian election. Party Politics, 7(4), 491-513.

Gregor, M. (2018). Where have all the pledges gone? An analysis of ČSSD and ODS Manifesto promises from 2002 to 2013. Politologický časopis - Czech Journal of Political Science, 25(2), $152-170$.

Harper, M. A. G. (2000). Economic voting in postcommunist Eastern Europe. Comparative Political Studies, 33(9), 1191-1227.

Harteveld, E., van der Brug, W., Dahlberg, S., \& Kokkonen, A. (2015). The gender gap in populist radical-right voting: Examining the demand side in Western and Eastern Europe. Patterns of Prejudice, 49(1,2), 103-134.

Haughton, T., \& Havlík, V. (2017). A few cracks in the cement: Regulation and the development of party politics in the Czech Republic. In I. van Biezen \& F. Casal Bértoa (Eds.), The regulation of post-communist party politics (pp. 85-105). London: Routledge.

Haughton, T., Novotná, T., \& Deegan-Krause, K. (2011). The 2010 Czech and Slovak parliamentary elections: Red cards to the 'winners'. West European Politics, 34(2), 394-402. https://doi.org/10.10 80/01402382.2011.546584

Havelka, M. (1998). "Nepolitická politika": kontexty a tradice. Sociologický časopis, 34, 455-466.

Havlík, V. (2015). Stable or not? Patterns of party system dynamics and the rise of the new political parties in the Czech Republic. Romanian Journal of Political Science,15(1), 180-202.

Havlík, V. (2015). The economic crisis in the shadow of political crisis: The rise of party populism in the Czech Republic. In H. Kriesi \& T. S. Pappas (Eds.), European populism in the shadow of the great recession (pp. 199-216). Colchester: ECPR Press.

Jankajová, E. (2013). "Vyhral Babišovi volby marketing?» Čas.sk. Available at: http://www.cas.sk/ clanok/264922/vyhral-babisovi-volby-marketing.html 
Katz, R. S., \& Mair, P. (1995). Changing models of party organization and party democracy: The emergence of the cartel party. Party Politics, 1, 5-28.

Klar, S., \& Krupnikov, Y. (2016). Independent politics. Cambridge: Cambridge University Press.

Klíma, M. (1998). Consolidation and stabilization of the party system in the Czech Republic. Political Studies, 46, 492-510.

Kopeček, L. (2016). 'I'm paying, so I decide' Czech ANO as an extreme form of a business-firm party. East European Politics and Societies, 30, 725-749.

Kopeček, L., \& Svačinová, P. (2017). Between organizational extremes: Czech parties after a political earthquake. In K. Sobolewska-Myslik, B. Kosowska-Gąstoł, \& P. Borowiec (Eds.), Organizational structures of political parties in central and eastern European countries (pp. 133-158). Krakow: Jagielonian University Press.

Lewis-Beck, M. S., \& Paldam, M. (2000). Economic voting: An introduction. Electoral Studies, 19(2), 113-121.

Lewis, P. G. (2006). Party systems in post-communist central Europe: Patterns of stability and consolidation. Democratization, 13(4), 562-583.

Lijphart, A. (1992). Democratization and constitutional choices in Czecho-Slovakia, Hungary and Poland 1989-91. Journal of Theoretical Politics, 4(2), 207-23.

Linek, L. (2003). Dimenze antistranických postojů české veřejnosti. Naše společnost, 1, 13-18.

Mainwaring, S., Gervasoni, C., \& España-Najera, A. (2017). Extra-and within-System electoral volatility. Party Politics, 6, 623-635.

Mair, P. (2002). Populist democracy vs party democracy. In Y. Mény \& Y. Surel (Eds.), Democracies and the populist challenge (pp. 81-98). London: Palgrave Macmillan.

Mair, P. (2013). Ruling the void: The hollowing of western Democracy. New York: Verso Books.

Meer, T. van der. (2018). Economic performance and political trust. In E.M.Uslaner (Ed.), Oxford handbook of social and political trust. Available online: https://www.oxfordhandbooks.com/ view/10.1093/oxfordhb/9780190274801.001.0001/oxfordhb-9780190274801-e-16

Mudde, C. (1996). The paradox of the anti-party party: Insights from the extreme right. Party Politics, 2, 265-276.

Pedersen, M. N. (1979). The dynamics of European party systems: Changing patterns of electoral volatility. European Journal of Political Research, 7, 1-26.

Poguntke, T. (1996). Anti-party sentiment - conceptual thoughts and empirical evidence: explorations into a minefield. European Journal of Political Research, 29, 319-344.

Poguntke, T., \& Scarrow, S .E. (1996). The politics of anti-party sentiment: Introduction. European Journal of Political Research, 29, 257-262.

Poláková, M., \& Kostelecký, T. (2016). Povolání zvolených poslanců za první republiky a dnes. Středoevropské politické studie, 18, 1-30.

Powell, E. N., \& Tucker, J.A. (2014). Revisiting electoral volatility in post-communist countries: New data, new results and new approaches. British Journal of Political Science, 44(1), 123-147.

Powell, G. B., \& Whitten, G. D. (1993). A cross-national analysis of economic voting: Taking account of the political context. American Journal of Political Science, 37(2), 391-414.

Rasmussen, M., \& Knutsen, C.H. (2017). Party institutionalization and welfare state development. Available at: https://www.researchgate.net/publication/281824526_Party_Institutionalization_and_ Welfare_State_Development

Roberts, A. (2016). What do we know and what do we need to know about mass-elite linkages in the Czech Republic? Acta Politologica, 8, 31-50.

Sartori, G. (1968). Representational systems. International encyclopedia of the social sciences (pp. 470-475). New York: Crowell-Collier-Macmillan.

Sartori, G. (2005). Parties and party systems: A framework for analysis. Colchester: ECPR Press.

Schattschneider, E. (2017). Party government: American government in action. Abingdon: Routledge. 
Schmitt, H. (1989). On party attachment in western Europe and the utility of Eurobarometer data. West European Politics, 12, 122-39.

Sing, M. (2004). Origins of anti-partyism in Hong Kong. East Asia, 21, 37-57.

Spierings, N., \& Zaslove, A. (2017). Gender, populist attitudes, and voting: Explaining the gender gap in voting for populist radical right and populist radical left parties. West European Politics, 40, 821847.

Škvrňák, M. (2015). Election pledges in the Czech Republic (2010-2013). Politologický časopis-Czech Journal of Political Science, 22, 216-237.

Svačinová, P. (2016). Slibem nezarmoutî̌? Naplňování socioekonomických legislativních slibů českých vládních stran (2006-2015). Sociologický časopis/Czech Sociological Review, (52), 709-736.

Tan, P. (2012). Anti-party attitudes in Southeast Asia. In D. Tomsa \& A. Ufen (Eds.), Party politics in Southeast Asia (pp. 98-118). Abingdon: Routledge.

Tavits, M. (2008). On the linkage between electoral volatility and party system instability in central and eastern Europe. European Journal of Political Research, 47, 537-555.

Torcal, M., Gunther, R., \& Montero, J. R. (2002). Anti-party sentiments in southern Europe. In R. Gunther, J.R. Montero, \& J. J. Linz (Eds.), Political parties. Old concepts and new challenges (pp. 257-290). Oxford: Oxford University Press.

Webb, P. (1996). Apartisanship and anti-party sentiment in the United Kingdom: Correlates and constraints. European Journal of Political Research, 29, 365-382.

Department of Political Science

Masaryk University

Joštova 10

60200 Brno

Czech Republic

Email: havlik@fss.muni.cz 